\title{
The Effect of Intermittent Pneumatic Compression Belt on Postnatal Diastasis Recti
}

\author{
KHADYGA S. ABD EL-AZIZ, Ph.D.*; ABD EL-RAHMAN H. ABD EL-WAHAB, M.D.**; \\ AFAF M. BOTLA, Ph.D.* and DOAA A. ABD AL-HADY, M.Sc.* \\ The Department of Physical Therapy for Obstetrics \& Gynecology, Faculty of Physical Therapy, Cairo University* and \\ The Department of Obstetrics \& Gynecology, Faculty of Medicine, El-Minia University**
}

\begin{abstract}
Background: Arising concern about intermittent pneumatic compression belt and its effect on postnatal diastasis recti.

Aim of Study: The aim of the present study was to determine the effect of intermittent pneumatic compression belt on postnatal diastasis recti.

Material and Methods: Thirty postnatal women with diastasis recti participated in this study. They were selected from Obstetrics and Gynecology outpatient clinic at El-Minia General Hospital, their age ranged from 25-35 years and their BMI was $25-35 \mathrm{~kg} / \mathrm{m}$, they were randomly distributed into two equal groups: Study group who received diet $(1200 \mathrm{kcal} /$ day), selected exercises program and intermittent pneumatic compression belt for six weeks and control group received diet $(1200 \mathrm{kcal} /$ day $)$ and selected exercises program for six weeks. Assessment of all women in both groups was carried out before and after treatment program through assessment of weight, BMI, waist circumference, $\mathrm{W} / \mathrm{H}$ ratio, inter-recti distance (above and below umbilicus) and abdominal fat thickness.

Results: There was a statistical significant improvement (decrease) in weight, BMI, waist circumference, waist/hip ratio, inter-recti distance (above and below umbilicus) and abdominal fat thickness in both groups but in favoring to Group A.

Conclusion: Usage of intermittent pneumatic compression belt is an effective method for reducing inter-recti separation and abdominal fat thickness in postnatal diastasis recti.
\end{abstract}

Key Words: Postnatal diastasis recti - Intermittent pneumatic compression belt.

\section{Introduction}

DIASTASIS recti is separation between the left and right side of rectus abdominis muscle, separation can occur any time in the last half of pregnancy but is most problematic after pregnancy when the

Correspondence to: Dr. Khadyga S. Abd El-Aziz,

The Department of Physical Therapy for Obstetrics \& Gynecology, Faculty of Physical Therapy, Cairo University abdominal wall is weak. Abdominal separation or diastasis recti reduce the integrity and functional strength of abdominal wall and aggravate lower back pain and pelvic instability [1]

Abdominal belt improves the strength of abdomen, thereby increases the intra-abdominal pressure that contributes to mechanical spine stability through co activation of trunk flexors and extensor musculature. As the abdominals contract, intra abdominal pressure increases and converts the abdomen into rigid cylinder that greatly increases the stability of the spine, improves abdominal strength and decreases abdominal separation so the abdominal belt plays an important role in stabilization of the lumbar region during lifting, that associated with significant improvement of the lifting ability to perform ADL activities [2]

IPC device is comprised of gradual pressure gradients on lymph vessels, facilitates the lymph flow [3]. IPC have been shown to be effective physiologically as they improve lymphatic function and lymph flow [4]. Compression therapy is encouraged because the pressure applied on the body not only improves lymphatic and venous circulation but also stimulates muscle [5].

\section{Patients and Methods}

Patients were recruited from outpatient clinics of El-Minia General Hospital during period extended from May 2017 till November 2017, after agreeing to participate in the study. Patients were enrolled in the study is met the following criteria: (1) All the patients were diagnosed with diastasis recti of $2.5 \mathrm{~cm}(25 \mathrm{~mm})$ or more; (2) Their age ranged from 25-35 years; (3) Their Body Mass Index (BMI) ranged from $25-35 \mathrm{~kg} / \mathrm{m}^{2}$; (4) All women delivered normally. 
Exclusion criteria: Include any disease that interferes with exercises (asthma), any skin disease or sensitivity that interferes with the use of intermittent pneumatic compression belt, any chest disease or cardiac disease and women who had abdominal surgery.

Patients went through evaluation of diastasis recti by weight, BMI, waist circumference, waist/ hip ratio and using ultrasound image (Toshiba, Japan) to determine the inter- recti distance (above and below the umbilicus) and abdominal fat thickness.

This study was approved by the scientific committee of Faculty of Physical therapy, Cairo University, Egypt. A written consent was obtained from each patient after they were provided with a through description of the study.

\section{Statistical methods:}

Results were expressed as mean \pm standard deviation. The mean difference was calculated as the following: Difference=pre treatment-posttreatment.

Statistical analysis was conducted using independent $t$-test for comparison between normally distributed variables in the two groups and using Mann-Whitney test for comparison between not normally distributed variables in the two groups while using paired $t$-test for comparison between variables measured before and after treatment in the same group.

\section{Results}

1- BMI showed a statistically significant decrease $(p<0.001)$ in study group as well as in control group. It also, showed no a statistically significant difference between both groups post-treatment with $(p=0.569)$ (Table 1).

Table (1)

\begin{tabular}{llll}
\hline & \multicolumn{2}{c}{ BMI } & \\
\cline { 2 - 3 } & \multicolumn{1}{c}{$\begin{array}{c}\text { Group I } \\
(\mathrm{n}=15)\end{array}$} & $\begin{array}{c}\text { Group II } \\
(\mathrm{n}=15)\end{array}$ & $\begin{array}{c}p \text {-value } \\
\text { (I vs II) }\end{array}$ \\
\cline { 2 - 3 } & \multicolumn{1}{c}{$\begin{array}{c}\text { Range } \\
\text { Mean } \pm \text { SD }\end{array}$} & $\begin{array}{c}\text { Range } \\
\text { Mean } \pm \text { SD }\end{array}$ \\
\hline Pre-treatment & $(24.9-34.3)$ & $(24.7-34.7)$ & 0.701 \\
& $30.4 \pm 3$ & $30.8 \pm 3.4$ & \\
Post-treatment & $(23.3-31.6)$ & $(23.2-31.6)$ & 0.569 \\
& $27.8 \pm 2.6$ & $28.4 \pm 3$ & \\
Mean difference & 2.6 & 2.4 & \\
& $(6.3-11.4)$ & $(5.4-10.9)$ & 0.403 \\
Percent of decrease & $8.5 \pm 1.7$ & $8 \pm 1.8$ & \\
$p$-value (pre vs post) & $<0.001 *$ & $<0.001 *$ & \\
\hline
\end{tabular}

*: Significant level at $p$-value $<0.05$.
2- W/H ratio showed a statistically significant decrease in study group $(p<0.001)$ as well as in control group $(p<0.002)$. It also, showed a statistically significant increase in the percentage of decrease in Group A (4.2 \pm 2.3$)$ compared with Group B $(2.4 \pm 2.4)$ with $(p=0.008)$ (Table 2).

Table (2)

\begin{tabular}{|c|c|c|c|}
\hline & \multicolumn{2}{|c|}{$\mathrm{W} / \mathrm{H}$ ratio } & \multirow{3}{*}{$\begin{array}{l}p \text {-value } \\
\text { (I vs II) }\end{array}$} \\
\hline & $\underset{(n=15)}{\text { Group I }}$ & $\begin{array}{c}\text { Group II } \\
(\mathrm{n}=15)\end{array}$ & \\
\hline & $\begin{array}{c}\text { Range } \\
\text { Mean } \pm \text { SD }\end{array}$ & $\begin{array}{c}\text { Range } \\
\text { Mean } \pm \text { SD }\end{array}$ & \\
\hline Pre-treatment & $\begin{array}{l}(0.83-1.05) \\
0.92 \pm 0.06\end{array}$ & $\begin{array}{l}(0.8-0.98) \\
0.92 \pm 0.05\end{array}$ & 0.980 \\
\hline Post-treatment & $\begin{array}{l}(0.79-1.02) \\
0.88 \pm 0.06\end{array}$ & $\begin{array}{l}(0.78-0.97) \\
0.9 \pm 0.05\end{array}$ & 0.411 \\
\hline Mean difference & 0.04 & 0.02 & \\
\hline (\$) Percent of decrease & $\begin{array}{l}(1.4-10.4) \\
4.2 \pm 2.3\end{array}$ & $\begin{array}{l}(0.4-10.2) \\
2.4 \pm 2.4\end{array}$ & $0.008^{*}$ \\
\hline$p$-value (pre vs post) & $<0.001 *$ & $0.002 *$ & \\
\hline
\end{tabular}

*: Significant level at $p$-value $<0.05$.

3- Waist circumference showed a statistically significant decrease in study group $(p<0.001)$ as well as in control group. It also, showed a statistically significant increase in percentage of decrease in Group A (10.6 \pm 2.2$)$ compared with its corresponding in Group B $(8.3 \pm 2.8)$ with $(p=0.019)$ (Table 3).

Table (3)

\begin{tabular}{llll}
\hline & \multicolumn{2}{c}{ Waist circumference } & \\
\cline { 2 - 3 } & $\begin{array}{c}\text { Group I } \\
(\mathrm{n}=15)\end{array}$ & $\begin{array}{c}\text { Group II } \\
(\mathrm{n}=15)\end{array}$ & $\begin{array}{c}\text { p-value } \\
\text { (I vs II) }\end{array}$ \\
\cline { 2 - 3 } & $\begin{array}{c}\text { Range } \\
\text { Mean } \pm \text { SD }\end{array}$ & $\begin{array}{c}\text { Range } \\
\text { Mean } \pm \text { SD }\end{array}$ & \\
\hline Pre-treatment & $(93-123)$ & $(84-120)$ & 0.848 \\
Post-treatment & $105.1 \pm 9$ & $104.5 \pm 9.8$ & \\
& $(80-110)$ & $(80-111)$ & 0.574 \\
Mean difference & $94 \pm 8.1$ & $95.7 \pm 8.6$ & \\
& 11.1 & 8.8 & $0.019 *$ \\
Percent of decrease & $10.6 \pm 2.2$ & $8.3 \pm 2.8$ & \\
$p$-value (pre vs post) & $<0.001 *$ & $<0.001 *$ & \\
\hline *: Significant level at $p$-value $<0.05$. & & \\
\hline
\end{tabular}

4- Inter-recti distance (above umbilicus) showed a statistically significant decrease in study group $(p<0.001)$ as well as in control group. It also, showed that there was statistical significant de- 
crease in the mean value of inter-recti distance (above umbilicus) post-treatment in Group A (14.3 \pm 3.4) compared with Group B $(18.1 \pm 4)$ with $(p=$ 0.011 ) and showed statistically significant increase in the percentage of decrease in Group A (48.7 \pm 11.4) compared with Group B $(37.5 \pm 8.5)$ with $(p=$ 0.005) (Table 4).

\begin{tabular}{|c|c|c|c|}
\hline \multicolumn{4}{|c|}{ Table (4) } \\
\hline & \multicolumn{2}{|c|}{ Above umbilicus } & \multirow{3}{*}{$\begin{array}{r}p \text {-value } \\
\text { (I vs II) }\end{array}$} \\
\hline & $\begin{array}{l}\text { Group I } \\
(n=15)\end{array}$ & $\begin{array}{c}\text { Group II } \\
(\mathrm{n}=15)\end{array}$ & \\
\hline & $\begin{array}{c}\text { Range } \\
\text { Mean } \pm \text { SD }\end{array}$ & $\begin{array}{c}\text { Range } \\
\text { Mean } \pm \text { SD }\end{array}$ & \\
\hline Pre-treatment & $\begin{array}{l}(25-34) \\
27.9 \pm 2.5\end{array}$ & $\begin{array}{l}(25-35) \\
28.7 \pm 3.2\end{array}$ & 0.450 \\
\hline Post-treatment & $\begin{array}{l}(9-20) \\
14.3 \pm 3.4\end{array}$ & $\begin{array}{l}(13-25) \\
18.1 \pm 4\end{array}$ & $0.011^{*}$ \\
\hline Mean difference & $\begin{array}{l}13.6 \\
(25.9-64)\end{array}$ & $\begin{array}{l}10.6 \\
(25-50)\end{array}$ & $0.005^{*}$ \\
\hline Percent of decrease & $48.7 \pm 11.4$ & $37.5 \pm 8.5$ & \\
\hline$p$-value (pre vs post) & $<0.001 *$ & $<0.001 *$ & \\
\hline
\end{tabular}

*: Significant level at $p$-value $<0.05$.

5- Inter-recti distance (below umbilicus) showed a statistically significant decrease in study group $(p<0.001)$ as well as in control group. It also, showed no statistically significant difference in percentage of decrease in Group A compared with Group B with $(p=0.058)$ (Table 5).

Table (5)

\begin{tabular}{|c|c|c|c|}
\hline & \multicolumn{2}{|c|}{ Below umbilicus } & \multirow{3}{*}{$\begin{array}{r}p \text {-value } \\
\text { (I vs II) }\end{array}$} \\
\hline & $\begin{array}{c}\text { Group I } \\
(n=15)\end{array}$ & $\begin{array}{c}\text { Group II } \\
(\mathrm{n}=15)\end{array}$ & \\
\hline & $\begin{array}{c}\text { Range } \\
\text { Mean } \pm \text { SD }\end{array}$ & $\begin{array}{c}\text { Range } \\
\text { Mean } \pm \text { SD }\end{array}$ & \\
\hline Pre-treatment & $\begin{array}{l}(8-11) \\
9.4 \pm 0.9\end{array}$ & $\begin{array}{l}(8-12) \\
9.2 \pm 1.2\end{array}$ & 0.612 \\
\hline Post-treatment & $\begin{array}{l}(5-8) \\
6.1 \pm 1\end{array}$ & $\begin{array}{l}(5-9) \\
6.5 \pm 0.9\end{array}$ & 0.260 \\
\hline Mean difference & $\begin{array}{l}3.3 \\
(20-45.5)\end{array}$ & $\begin{array}{l}2.7 \\
(22.2-37.5)\end{array}$ & 0.058 \\
\hline Percent of decrease & $34.6 \pm 9.9$ & $28.9 \pm 5.1$ & \\
\hline$p$-value (pre vs post) & $<0.001 *$ & $<0.001 *$ & \\
\hline
\end{tabular}

$*$ : Significant level at $p$-value $<0.05$.

6- Abdominal fat thickness showed a statistically significant difference in study group $(p<0.001)$ as well as in control group. It also, showed that there was statistical significant decrease in the mean value of abdominal fat thickness post treatment in Group A (13.1 \pm 4$)$ compared with Group B (16.9 \pm 5.1$)$ with $(p=0.030)$ and showed a statistically significant increase in the percentage of decrease in Group A $(46.6 \pm 7.9)$ compared with Group B $(31.8 \pm 5.1)$ with $(p=0.001)$ (Table 6).

Table (6)

\begin{tabular}{llll}
\hline & \multicolumn{2}{c}{ Abdominal fat thickness } & \\
\cline { 2 - 3 } & $\begin{array}{c}\text { Group I } \\
(\mathrm{n}=15)\end{array}$ & $\begin{array}{c}\text { Group II } \\
(\mathrm{n}=15)\end{array}$ & $\begin{array}{c}\text { p-value } \\
\text { (I vs II) }\end{array}$ \\
\cline { 2 - 3 } & $\begin{array}{c}\text { Range } \\
\text { Mean } \pm \text { SD }\end{array}$ & $\begin{array}{c}\text { Range } \\
\text { Mean } \pm \text { SD }\end{array}$ & \\
\hline Pre-treatment & $(13-33)$ & $(12-35)$ & 0.979 \\
Post-treatment & $24.7 \pm 6.6$ & $24.7 \pm 7$ & \\
& $(7-20)$ & $(9-27)$ & $0.030 *$ \\
Mean difference & $13.1 \pm 4$ & $16.9 \pm 5.1$ & \\
& 11.6 & 7.8 & $<0.001 *$ \\
Percent of decrease & $46.6 \pm 7.9$ & $31.8 \pm 5.1$ & \\
$p$-value (pre vs post) & $<0.001 *$ & $<0.001 *$ & \\
\hline
\end{tabular}

$*$ : Significant level at $p$-value $<0.05$.

\section{Discussion}

The main findings of the present study confirmed that there was significant effect of intermittent pneumatic compression belt on postnatal diatasis recti.

The results of this study agreed with Donovan [6] who proved that the abdominal belt can reduce the waist circumference $2 \%$ each week and can attain a 10 inch reduction of its original waist circumference after 6 weeks of use.

They were also supported by Lynn-Mcdonough [7] who reported that using the postpartum girdle immediately after giving birth and wearing it for 40 days, together with breast feeding and abdominal exercises help to return the abdominal muscles to its pre-pregnancy shape and loss of abdominal fat.

The results of this study supported by Maeo et al., [8] who reported that abdominal bracing is one of the most effective techniques for inducing a higher activation in abdominal muscles.

The results of this study were in disagreement with Fayolle-Minon and Calmels [9] who carried out a study on twenty subjects using abdominal support for 8 hours daily over a period of 21 days and they concluded that there was no significant change in isokinetic and isometric strength of trunk muscles. 
This study was subjected to several limitations. First, personal and individual differences between the subjects. Second, cooperation of the patients may have affected the result of study. Third, environmental factors which may have affected the subject's response. Fourth, the patient's ability to follow up instruction that was given to them.

\section{References}

1- TUPLER J. and GLOUD J.: Lose your mummy flatten your stomach now. J. of Chriopractors Assoc., 7: 55-63, 2005.

2- WARREN L., APPLING S., OLADEHIN A. and GRIFFIN J.: Effect of soft lumbar support belt on abdominal oblique muscle activity in non impaired adults during squat a lifting. Orthop. Sports J., 31 (6): 3 16-23, 2001.

3- KOZANGOLU E., BASARAN S., BAYDASS and SARPEL T.: Efficiency of pneumatic compression and low level laser therapy in treatment of post mastectomy lymph edema. Clinic Rehab J., (23): 117-24, 2009.
4- ADAMS K., RAMUSSEND C. and DAME C.: Direct evidence of lymphatic function improvement after advanced pneumatic compression device treatment of lymphedema. Biomed Opts Express, 46 (4): 114-25, 2010.

5- VIGNES S., PORCHER R., ARRAULT M. and DUPUY A.: " Long term management of breast cancer related lymphedema after intensive decongestive physiotherapy". Breast Cancers Res. Treat. J., (101): 285-90, 2007.

6- DONOVAN D.: Help you get in shape? Corset will. Sunday Mirror, 5 (7): 11-3, 2006.

7- LYNN-MCDONOUGH V.: Postpartum abdominal binder. Postpartum Wellness Assoc. J., 10 (5): 35-7, 2010.

8- MAEO S., TAYASHIKI K., TAKAI Y. and KANEHISA H.: Trunk muscle activities during abdominal brace: Comparing among muscle and exercises. J. of Sports Sciences Med., (12): 467-74, 2013.

9- FAYOLLE-MINON I. and CAMELS H.: "Effect of wearing lumber orthosis on trunk muscles, study of muscle strength after 21 of use on healthy subjects". Joint bone spine J., 75 (1): 58-63, 2008.

\title{
تآثير الحزام الهوائى الضاغط الهتقطع على إنفراق

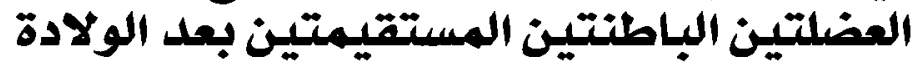

\author{
الهدف: آجريت هذه الدراسة لتصديد تآثير الحزام الهوائى الضاغط المتقطع على إنفراق العضلتين الباطنتين المستقيمتين بعد الولادة.

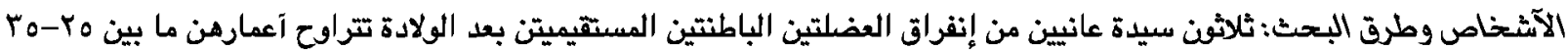

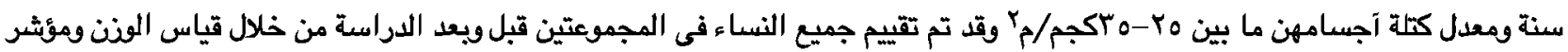

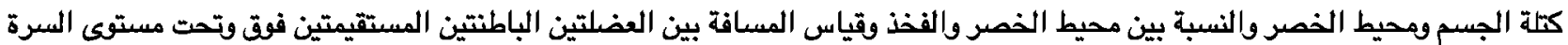 \\ وكذلك سمك دهون البطن من خلال الآشعة تليفزيونية.

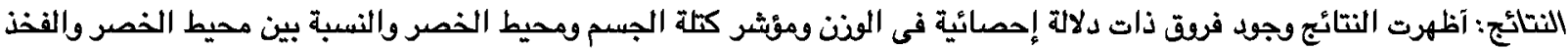

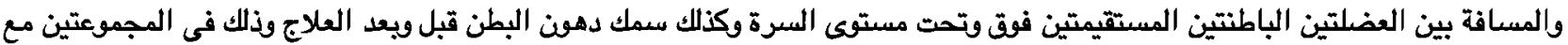

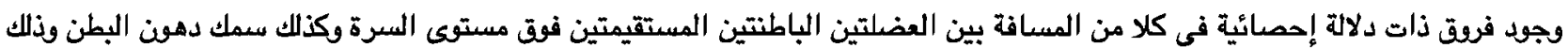 \\ لمالح المجموءة (آ). \\ الإستتاج: إستخدام الحزام الهوائي الضاغط المتقطع بعد الولادة وسيلة فعالة في حالات إنفراق العضلتين الباطنتين المستقيمتين بعد
}

